It is proposed to improve the legal system of Ukraine by assessing the effectiveness of the norms of law, control, analysis, generalization, monitoring of the quality of normative legal acts and practices of their application, forecasting directions of development of legal regulation of social relations.

Key words: legal monitoring, legal regulation, legal expertise, normative legal act, legal conflicts.

DOI: 10.33.66.3/2524-017X-2019-10-87-94

УДК 340

\begin{abstract}
Анатолій Свгенійович Шевченко, доктор юридичних наук, професор, професор кафедри теорії, історії права і держави та конституиійного права ННІП Університету державної фіскальної служби України
\end{abstract}

Алла Вікторівна Старостюк, кандидат юридичних наук, доиент, доцент кафедри теорії, історії права і держави та конституиіийного права ННІП

Університету державної фіскальної служби Украӥни

\title{
ВІДРОДЖЕННЯ ДОВІРИ ДО ПРАВА ЯК ПОКАЗНИК ЕФЕКТИВНОСТІ ПРАВОВОГО МОНІТОРИНГУ
}

Постановка проблеми. Сучасний етап розвитку України, який характеризується наявністю кризових явищ у багатьох сферах суспільного життя, потребує зосередження особливої уваги на питаннях відродження довіри до права як ефективного регулятора суспільних відносин. Варто зазначити, що ситуація, яка пов'язана із скептичним відношенням до права і недооціненням його можливостей в суспільній свідомості, виникла не миттєво. Вона $є$ наслідком існування багатьох трагічних сторінок нашої історії та довготривалого періоду нехтування цінностями права.

Виникає цілком закономірне питання: як могло статися, що такі фундаментальні цінності, як справедливість, свобода, відповідальність, довіра до права, досить важко закріплюються у якості основи формування поведінкових орієнтацій учасників суспільних відносин, а ситуація у сфері правотворчості, процесу забезпечення реалізації прав і свобод людини та громадянина в Україні набуває загрозливого характеру? Вважаємо, що однозначної відповіді на це запитання не знайдемо, оскільки вона залежить від аналізу цілого ряду чинників, які призвели до такого результату. Беззаперечним $\epsilon$ те, що в масовій суспільній свідомості міцно закріпили свої позиції правовий нігілізм, падіння довіри до правових інститутів, влади та її представників.

Аналіз останніх досліджень та публікацій. На теоретичному рівні розкриття сутності питань, які пов'язані з відродженням довіри до права, базовими $є$ наукові роботи, що стосуються проблем праворозуміння, дії права, функціонування та здійсненням державної влади. В зазначеному контексті спостерігаємо наявність вагомого внеску українських науковців щодо висвітлення зазначеної проблематики. Серед представників вітчизняної наукової еліти, які вивчали і продовжують брати активну участь в дослідженні цих питань, імена таких вчених, як С. Бобровник, Т. Дідич, А. Колодій, М. Козюбра, Н. Оніщенко, А. Селіванов, П. Рабінович, О. Тихоміров, В. Шаповал, Ю. Шемшученко та ін.

Мета статті - виявлення можливостей відродження довіри до права як результату ефективного процесу здійснення правового моніторингу.

Основні результати дослідження. Виходячи з розуміння того, що право - це мистецтво добра і справедливості (Ульпіан), відродження довіри до нього має розпочинатися з позицій забезпечення реалізації його ціннісних характеристик, саме з боку тих суб’єктів, діяльність яких пов'язана 3 процесом здійснення владних функцій, тобто представників державної влади. Варто пригадати думку А. Селіванова, який зазначав, що «рух країни до реального втілення в державне і суспільне життя цінностей права, побудови громадянського суспільства, панування правового закону і право- 
вої держави має конкретну мету - утвердження непорушних прав і свобод людини і громадянина, що вимагає від народних обранців прийняття не тільки суспільно вагомих рішень, але й принципового ставлення до будь-яких проявів корозії публічної влади, нехтування інтересами народу з боку управлінського апарату, працівників державних органів» [1, с. 3].

Утвердження цінностей права (свободи, рівності, справедливості), що має на меті забезпечення реалізації прав і свобод людини та громадянина, передбачає відродження довіри до права та його ролі в житті суспільства.

«3 точки зору соціальних наук довіра - це культурна установка на особливе сприйняття «іншого» і взаємодія з ним. Довіра має на увазі, що «інший» поведеться (чи не поведеться) в певних справах певним чином. Такий тип соціокультурних взаємодій спочатку формується і далі існує як позитивний, оскільки характеризується відкритістю, упевненістю в надійності «іншого» - індивіда, групи, структури. «Іншим» може виступати будь-який об'єкт соціальної реальності, в тому числі право, структури влади, закони, держава тощо. За наявності довіри, наприклад, до права суб'єкти підкоряються йому не з примусу, а за переконанням, що є базисом для функціонування правового суспільства»[2, с. 118].

Варто зазначити, що за період існування України як незалежної держави не здійснено належні кроки на шляху визнання домінуючої ролі права в контексті функціонування державної влади та усвідомлення того, що всі органи державної влади повинні здійснювати свою діяльність на основі принципів і норм права. Так, існуючі порушення прав громадян з боку владних структур призвели до того, що Україна займає четверте місце серед звернень громадян інших держав до Європейського суду з прав людини [3, с.16]. За таких умов залишається актуальним питання про наявність загрози повернення до авторитарного режиму.

Оскільки процес формування права та забезпечення втілення його в життя пов'язаний 3 діяльністю законодавчої, виконавчої та судової гілок влади, відновлення довіри до нього знаходиться в прямій залежності від рівня довіри саме до цих владних структур. В зв'язку з цим постає цілком закономірне питання: за наявності яких умов влада виконуватиме взяті на себе зобов'язання перед суспільством, а суспільство, в свою чергу, відновлюватиме довіру інститутів влади та права?

Вважаємо, що відповідь на це запитання знаходиться в площині реалізації принципу верховенства права (правового закону), складовою частиною якого $є$ принцип захисту довіри, який «передбачає, зокрема, забезпечення: впевненості громадян у тому, що їх правове становище залишатиметься стабільним і в майбутньому не погіршуватиметься; публічності діяльності держави, стабільності законодавства та прогнозованості його розвитку; адекватного дискреційним повноваженням відповідних державних органів захисту від свавільних рішень; поваги держави до так званих «легітимних очікувань» (legitimate expectation), тобто до іï зобов'язань перед своїми громадянами та їхніх законних очікувань ( наприклад, у сфері трудових відносин - повага до встановлених законом критеріїв оплати праці; у сфері кримінальної відповідальності - повага до права засудженого на звільнення від покарання чи дострокове звільнення від відбування покарання тощо); закріплення у законі недопустимості «змін до гіршого» (reformation in pejus), тобто погіршення правового становища особи, яка оскаржує рішення про притягнення іiі до юридичної відповідальності (наприклад, застосування вищою судовою інстанцією суворішої санкції до підсудного при оскарженні ним вироку суду нижчої інстанції, посилення адміністративного чи дисциплінарного стягнення при оскарженні рішень відповідних органів чи посадових осіб).

Одним з найважливіших складових принципу захисту довіри $є$ незворотність дії закону у часі» $[4$, c. $371-372]$.

Усвідомлюючи важливість принципу верховенства права в процесі здійснення владних повноважень, варто пам'ятати, що співвідношення права і влади - це співвідношення не однозначного характеру. На це звертає увагу С. Алексєєв, зазначаючи, що «влада, особливо влада політична, державна, яка і робить «право правом», у той же час - явище, якоюсь мірою 3 ним несумісне, виступає стосовно права у вигляді протиборчого, а часом і далекого, гостро ворожого чинника» [5, с. 67]. Вчений підкреслює, що «владна сила здатна зменшувати право, перетворювати його на «слугу» влади, тим самим фактично створюючи «неправову» реальність [6].

Виправити таку ситуацію, на нашу думку, можливо шляхом зменшення негативного впливу влади на право, що передбачає модернізацію існуючої політичної системи суспільства, а також: «введення кримінальної відповідальності для депутатів всіх рівнів за шахрайські дії у випадку свідомого порушення ними передвиборчих обіцянок; здійснення фінансування громадського телета радіомовлення самими громадянами, керівниками, якого можуть бути лише особи, не пов'язані 
з державною службою; введення постійного моніторингу дій влади з боку громадянського суспільства шляхом створення постійно діючих органів, утримання яких теж планується за рахунок прямих податків громадян (за аналогією зі спостережною радою акціонерного товариства); укладання 3 вищими посадовими особами держави контрактів 3 представниками громадянського суспільства, звітування перших раз на рік перед громадянами, які їх обрали (перший рік каденції раз на півроку), у випадку негативної оцінки - усунення від посади; створення суду присяжних для розгляду всіх справ, де обвинувачення висувається проти громадянина у скоєнні кримінального правопорушення, за яке можливе покарання у вигляді позбавлення волі; створення спеціального органу з числа науковців юристів для контролю за дотриманням прав громадян з боку суддів при здійсненні ними правосуддя; визнання джерелами права теорії природного права...» [7, с. 369-370].

Усвідомлюючи беззаперечний вплив влади на процес формування та дії права, варто пам'ятати про витоки, звідки бере свій початок влада. У висвітленні цього питання ми знову повертаємося до народу як джерела влади. Враховуючи те, що народ має в своєму розпорядженні реальні механізми впливу на владу, на нашу думку, не варто покладати відповідальність лише на суб'єктів влади.

Однак тут існує інша проблема, яка пов'язана з існуванням кризового стану, в якому перебуває сучасне українське суспільство, що негативно позначається на його політичній і правовій культурі. За таких умов народ здатний лише до виявлення псевдодемократії, а не об'єктивної оцінки ситуації і розв'язання відповідних проблемних питань. Перехід до «культурної демократії», яка передбачає існування належного рівня соціальної культури народу, важливими складовими якої є розвиток «ідеологічної, політичної економічної, правової, моральної, релігійної та іншої культури громадян» [8] - це чи не найважливіше завдання сучасного українського суспільства.

Подолання кризових явищ у багатьох сферах суспільного життя, врахування об'єктивних законів розвитку суспільства, відновлення довіри до права необхідно розглядати ще й як складову частину національної безпеки України. Це передбачає усвідомлення того, що «... навіть найкращі у світі інструменти безпеки (ті, що засновані на останніх досягненнях фізичних і біологічних наук та технологій) не можуть самі по собі забезпечити національну безпеку у країні, якщо їі громадяни не мають розвинутої соціальної культури, відповідно до якої ці інструменти вони повинні приводити в дію, тобто застосовувати. Понад те, деякі інструменти безпеки здатні також виступати чинником загрози національній безпеці, якщо ними користуватимуться громадяни, які не мають належної соціальної культури. ... Тому саме народ, що має відповідний рівень соціальної культури, $\epsilon$ основним антикризовим чинником - гарантом національної безпеки. Соціальна культура громадян - наймогутніша зброя для забезпечення національної безпеки» [9] .

Варто зазначити, що соціальна культура передбачає необхідність відходу від психологічного сприйняття стереотипів, які все ще знаходять своє відображення у свідомості багатьох громадян, стосуючись моделі взаємовідносин особи і держави. Залежність особи від держави, а в подальшому і неможливість знайти своє місце у новій соціальній системі - це наслідок тієї негативної спадщини, яка дісталась нашому суспільству від років існування радянської влади.

Так, наприклад, «Українська правда» «вивчила дослідження Центру Разумкова, ще два - групи «Рейтинг», поговорила з соціологами та істориками, заглибилася у їхні наукові праці й врешті відтворила збірний образ українця, що ностальгує за СРСР... Багатші люди з вищим рівнем освіти менше сумують за СРСР. Натомість сумують ті, хто найбільше втратили... Це перш за все бажання повернутися туди, «де було добре»... Найчастіше свій жаль люди пояснють тим, що за часів Союзу «існувала впевненість у завтрашньому дні», «високий рівень соціальних гарантій», «безкоштовна вища освіта», «відсутність безробіття» і «достатній матеріальний рівень життя»...

Ностальгію за Радянським Союзом науковці також порівнюють із сумом за «великим батьком».

Україні властивий патерналізм - політична практика, коли народ сприймається як «дитина», котра потребує «батьківської уваги» влади. I населення очікує, що змінювати країну повинна саме влада [10].

Як стверджує соціолог Л. Гудков, для такого типу людей характерним є: масовидність, або бажання «бути як всі»; пристосуванство і адаптація до існуючого соціального порядку, готовність вимагати менше; простота і обмеженість в інтелектуальному та етичному планах (при цьому свою примітивність «радянська людина» вважає перевагою); ієрархічність (таким людям далеке поняття «еліти»); хронічна невдоволеність тим, що «дало життя»; невпевненість у собі; комплекс недооціненості; свою розчарованість і недооціненість «радянська людина» компенсує відчуттям винятковості і зверхності тощо [11]. 
Подолання всіх негативних характеристик, які властиві для «радянської людини», не може відбутися протягом короткотривалого періоду часу. Зміна ціннісних орієнтацій і психологічних установок людини потребує значних затрат як ідеологічного, так і матеріального характеру з метою формування об'єктивної оцінки реальної дійсності та готовності до активної поведінки в процесі правотворчості та реалізації права.

У вирішенні цього питання важливу роль має відігравати правова культура, яку доцільно розглядати як якісний стан правового життя суспільства, як систему правових цінностей, що покладені в основу правотворчої та правозастосовної діяльності. Однак правова культура не є чимось сталим інезмінним. Стан правової культури суспільства залежить від багатьох чинників, які обумовлюють її рівень.

Ситуація ускладнюється тим, що негативно позначається на рівні правосвідомості і правової культури сучасного українського суспільства проблеми щодо функціонування державної влади; криза у сфері економічних та політичних відносин; наростання невдоволення населення країни повільними темпами реформаційних процесів тощо.

Однак, незважаючи на всі проблемні питання, які безпосередньо стосуються сучасного етапу розвитку українського суспільства і української держави, іншого шляху, ніж шлях розвитку на основі ефективних нормативних моделей, не існує. Суспільство, виникаючи як структура нормативно встановленої й координованої поведінки, відіграє визначальну роль у формуванні загальнообов'язкових моделей поведінки (права), а право, в свою чергу, створює умови для злагодженого функціонування системи суспільних відносин.

Висновки. Таким чином, розглянувши питання відновлення довіри до права як важливого регулятора суспільних відносин слід зазначити, що ефективність функціонування апарату держави, належна реалізація принципів та норм права залежить не лише від того наскільки якісно здійснюватимуть свої функції органи державної влади, а й від ціннісного наповнення політичної і правової свідомості сучасного українського суспільства, рівня розвитку соціальної культури громадян.

Усвідомлюючи місце і роль людини в житті суспільства, неминуче порушуємо питання необхідності подолання ознак «радянської людини» та формування нових якостей людини сучасної, що $€$ неможливим без відновлення довіри до права та його цінностей. Саме від цього в остаточному підсумку буде залежати результат політико-правових реформ, якість правотворчої діяльності та весь процес функціонування інститутів влади і громадянського суспільства, забезпечення реалізації прав і свобод людини та громадянина.

\section{Список використаних джерел}

1. Депутатська недоторканність: (Сучасна парламентська та судова практика: правовий аналіз) О. В. Задорожній, А. О. Селіванов, М. В. Харитончук / За заг. ред. О. В. Задорожнього. - К. : Логос, 2004. - С. 3.

2. Суспільство, людина, право: сучасні дослідження актуальних проблем : моногр. / За ред. проф. О. Г. Данильна. - Харків, Право, 2014. - С.118.

3. Величук С. Н. Становлення та формування прецедентного права в Україні в контексті практики Свропейського суду з прав людини : автореф. дис. ... канд. юрид. наук : 12.00.01. / С. Н. Величук - К., 2014. - С. 16.

4. Козюбра М. I. Загальна теорія права : підруч. / За ред. М. І. Козюбри. - К., 2015. - С. 371-372.

5. Алексєєв С. С. Философия права [Текст] / С. С. Алексеев. - М. : Норма, 1997. - С. 67.

6. Там само.

7. Трансформація правової ідеології у контексті сучасних викликів : моногр. / За загальною ред. Н. М. Оніщенко. - Вінниця, «Нілан-ЛТД», 2016. - С. 369-370.

8. [Електронний ресурс]. - а Режим доступу : http://dspace.nbuv.gov.ua/bitstream/handle/123456789/45324/04Kostenko.pdf?sequence $=1$

9. Там само.

10. [Електронний ресурс]. - а Режим доступу : https://www.pravda.com.ua/rus/articles/2018/03/22/7175391/

11. Там само.

\section{References}

1. Deputatska nedotorkannist: (Suchasna parlamentska ta sudova praktyka: pravovyi analiz) O. V. Zadorozhnii, A. O. Selivanov, M. V. Kharytonchuk / Za zah. red. O. V. Zadorozhnoho. - K. : Lohos, 2004. - S. 3.

2. Suspilstvo, liudyna, pravo: suchasni doslidzhennia aktualnykh problem: monohrafiia / Za redaktsiieiu profesora O. H. Danylna. - Kharkiv, Pravo, 2014. - S.118. 
3. Velychuk S. N. Stanovlennia ta formuvannia preedentnoho prava v Ukraini v konteksti praktyky Yevropeiskoho sudu z prav liudyny: avtoref. dys. ... kand. yuryd. Nauk : 12.00.01. / S. N. Velychuk - K., 2014. - S.16.

4. Koziubra M. I. Zahalna teoriia prava: pidruchnyk / Za red. M. I. Koziubry. - K., 2015. - S. 371-372.

5. Aleksieiev S. S. Fylosofyia prava [Tekst] / S.S.Alekseev. - M. : Norma, 1997. - S. 67.

6. Tam samo.

7. Transformatsiia pravovoi ideolohii u konteksti suchasnykh vyklykiv : monohr. / Za zahalnoiu red. N. M. Onishchenko.Vinnytsia, «Nilan-LTD», 2016. - S. 369-370.

8. http://dspace.nbuv.gov.ua/bitstream/handle/123456789/45324/04-Kostenko.pdf?sequence=1

9. Tam samo.

10. https://www.pravda.com.ua/rus/articles/2018/03/22/7175391/

11. Tam samo.

\section{Шевченко А. Є., Старостюк А. В. Відродження довіри до права як показник ефективності правового моніторингу}

У статті розглядаються питання відновлення довіри до права як важливого регулятора суспільних відносин. Підкреслюється, що цей процес пов'язаний з функціонуванням законодавчої, виконавчої та судової гілок влади на основі принципу верховенства права, а також ціннісним наповненням політичної і правової свідомості сучасного українського суспільства, рівнем розвитку соціальної культури, складовими частинами якої є розвиток ідеологічної, політичної економічної, правової, моральної, релігійної та іншої культури громадян.

Соціальна культура передбачає необхідність відходу від психологічного сприйняття стереотипів, які все ще знаходять своє відображення у свідомості багатьох людей, стосуючись моделі взаємовідносин особи і держави. Залежність особи від держави, а в подальшому і неможливість знайти своє місце у новій соціальній системі є наслідком тієї «спадщини», яка дісталась українському суспільству від років існування радянської влади.

Подолання всіх негативних ознак, які властиві для «радянської людини», не може відбуватися протягом короткотривалого періоду часу. Зміна ціннісних орієнтацій і психологічних установок людини вимагає значних затрат як матеріального, так і ідеологічного характеру з метою формування об'єктивної оцінки реальної дійсності та готовності до активної поведінки в процесі правотворчості та реалізації права.

У вирішенні цього питання важливу роль має відігравати правова культура, яку доцільно розглядати як якісний стан правового життя суспільства, як систему правових цінностей, що покладені в основу правотворчої, правозастосовної діяльності та процесу реалізації норм права. Саме від цього в остаточному підсумку буде залежати відновлення довіри до права i, як результат - якість політико-правових реформ, весь процес функціонування інститутів влади та громадянського суспільства, забезпечення реалізації прав і свобод людини і громадянина.

Ключові слова: право, довіра, державна влада, принцип верховенства права, соціальна культура, правова культура.

\section{Shevchenko A. E., Starostyuk A. V. Revival of trust to the right as the indicator of efficiency of legal monitoring}

In article questions of restoration of trust to the right as important regulator of the public relations are considered. It is emphasized that this process is connected with functioning of legislative, executive and judicial branches of the power on the basis of the principle of the rule of law and also valuable filling of political and legal consciousness of modern Ukrainian society, the level of development of social culture which components are development of ideological, political economic, legal, moral, religious and other culture of citizens.

Social culture assumes need of leaving from psychological perception of stereotypes which still find the reflection in consciousness of many people, concerning model of relationship of the personality and the state. The dependence of the person on the State, and further and impossibility to find the place in a new social system is a consequence of that «inheritance» which got to the Ukrainian society of years of existence of the soviet power.

Overcoming all negative signs inherent for «the Soviet person» cannot happen during the short-term period of time. Change of valuable orientations and mental sets of the person demands considerable expenses of both material, and ideological character for the purpose of formation of objective assessment of reality and readiness for active behavior in the course of law-making and realization of the right.

In the solution of this question legal culture which is expedient for considering as a qualitative condition of legal life of society as the system of the legal values which are been the basis for law-making, law-enforcement activity and process of implementation of rules of law has to play an important role. Restoration of trust to the right and as result quality of political and legal reforms, all process of functioning of institutes of the power and civil society, ensuring realization of therights and freedoms of the person and citizen will depend on it in a residual result.

Key words: law, trust, state power, principle of the rule of law, social culture, legal culture.

DOI: 10.33.66.3/2524-017X-2019-10-94-98 